\title{
Effects of Campus Life Stress, Stress Coping Type, Self-esteem, and Maladjustment Perfectionism on Suicide Ideation among College Students
}

\author{
Seon-Uk Park ${ }^{1}$, Mi-Kyeong Kim ${ }^{2}$ \\ ${ }^{1}$ Department of Health \& Medical Administration, Gimhae College, Gimhae, Korea \\ ${ }^{2}$ Department of Clinical Laboratory Science, Gimhae College, Gimhae, Korea
}

\section{대학생의 대학생활 스트레스와 대처방식, 자아존중감, 부적응적 완벽주의가 자살생각에 미치는 영향}

\author{
박선욱 ${ }^{1}$, 김미경 ${ }^{2}$ \\ ${ }^{1}$ 김해대학교 보건의료행정과, ${ }^{2}$ 김해대학교 임상병리과
}

\begin{abstract}
The purpose of this study was to analyze the factors affecting suicidal ideation, and suggest the implications for suicide prevention policy among college students based on that analysis. Empirical model including the affecting factors, such as college life stress, stress coping type, self-esteem, and maladjustment perfectionism, was developed based on the previous studies. The data were collected from 350 college students at Busan Metropolitan City areas using a self-administered structured questionnaire. The major results of this study are as follows. First, suicidal ideation was significantly lower among students with higher campus life satisfaction. Second, significant positive affecting factors on suicidal ideation were maladjustment perfectionism, interpersonal stress, boys, emotion-oriented coping type, whereas, negative factors were self-esteem. Among the significant affecting factors, self-esteem had the greatest influence. These results suggest that measures improving college life satisfaction and education and training programs for improving human relation skills and stress-coping types, mitigating maladjustment perfectionism, and enhancing self-esteem should be explored and executed properly.
\end{abstract}

Key words: Suicidal ideation, Stress coping type, Self-esteem, Maladjustment perfectionism, College life satisfaction

\footnotetext{
This is an Open Access article distributed under the terms of the Creative Commons Attribution Non-Commercial License (http://creativecommons.org/licenses/by-nc/4.0) which permits unrestricted non-commercial use, distribution, and reproduction in any medium, provided the original work is properly cited.

Copyright () 2018 The Korean Society for Clinical Laboratory Science. All rights reserved.
}

\author{
Corresponding author: Mi-Kyeong Kim \\ Department of Clinical Laboratory Science, \\ Gimhae College, 112 Saman-ro, Gimhae \\ 50811, Korea \\ Tel: 82-55-320-1756 \\ Fax: 82-55-336-6251 \\ E-mail:mkkim@gimhae.ac.kr
}

Received: October 31, 2017

Revised $1^{\text {st. }}$ : December 4, 2017

Revised 2 ${ }^{\text {nd }}$ : December 6, 2017

Revised 3 ${ }^{\text {rd }}$ : December 7, 2017

Accepted: December 8, 2017

\section{INTRODUCTION}

The suicide mortality rate in Korea is the highest among the OECD member countries for 10 years since 2004 [1]. According to a survey by the National Statistical Office of the three major causes of death and mortality by age in
2016, deliberate self-harm (suicide) ranked first in the 10s, 20s and 30s, and second in the 40s and 50s [2]. In addition, an external cause of death was the highest among the elderly over 10 years of Recently, the World Health Organization (2014) announced that the cause of death of world youth 2 is suicide [3]. In Korea, the mortality rate 
trends by age of the elderly in 2009 2010 are as follows: The number of suicide deaths among 20 29 year olds is 24.4 per 100,000 , which is much higher than that of $10 \sim$ 19 year olds (5.2 per 100,000) [4].

For college students who are preparing to go to society just after getting out of adolescence and entering the early in the adult, they must cope with more life changes than any demographic groups, including physical development, increase in social and political awareness, identity formation, separation from family, friends and many of neighboring others, etc. Entering the early adolescence and early adulthood, youth can consider suicide or attempt to suicide impulsively due to difficulties that they can not cope with as an adult feeling complicated, confused, and sometimes frightened.

Previous studies on suicide have focused on factors such as suicidal ideation and attempted suicide as factors that can capture the signs of suicide due to the limitation that they can not directly study the subject who passed into the death due to suicide [5]. While suicide attempts are actually aspects of suicide, suicidal ideation refers to thinking about motivation, will, and planning to commit suicide as an accident involving the death of oneself.

The purpose of this study was to provide basic data for a suicide prevention plan for college students by identifying an impact of their college life stress, stress coping strategies, self-esteem, and maladaptive perfectionism on their suicidal ideation.

\section{MATERIALS AND METHODS}

\section{Study subjects and data collection}

For the subjects of this study, 350 college students were recruited from 4 universities in Busan Metropolitan City and Gimhae City from May 1 to May 15, 2010. For data, self-administered questionnaires were conducted using structured questionnaires. The questionnaire used in the data collection was revised and supplemented according to the purpose of the study with reference to the previously developed questionnaires. The questionnaire used in this study consisted of a total of 158 questions in a total of 6 areas including socio-demographic characteristics, college life stress, stress coping style, self-esteem, maladaptive perfectionism, and suicidal ideation.

\section{Tools}

1) College life stress scale

The college life stress scale question for college students used in this study is the life stress scale for college students developed in 1991 [6]. In this study, the revised, complemented questionnaire was used. In this scale, experience frequency and significance were set at 5 points for more detailed evaluation. More specifically, each participant was asked to rate the events they experienced during the past years on a 5 -point scale (1=not at all, $5=$ =very much). If they have experienced more than one incident during the past years, the importance is to be rated on a 5-point scale.

Also, the survey is composed of a total of 50 questions in 2 areas that apply to college students. In detail, the 2 areas are divided into an interpersonal relationships area that include relationships with opposite sex friends, same sex friends, family, and professors and into an facing tasks area including future, economic, values, and academic problems. In this study, the reliability of the scale was tested with the results of facing tasks stress 0.791 and interpersonal relationships stress 0.719 in Cronbach's $\alpha$ by sub-area.

\section{2) Stress coping strategies scale}

The stress coping scale used the scales of Kim and Lee [7], which were modified and supplemented by 68 items developed by Folkman and Lazarus [8]. It is made up of problem-oriented coping strategies of 21 questions and emotion-oriented coping strategies of 24 questions. Depending on the use of stress coping strategies, the questionnaire is composed of a 5 -point scale (1=not at all, 5=very much). In this study, the reliability of the scale was verified. As a result of that, Cronbach's $\alpha$ showed problem-oriented coping strategies 0.873 and emotion-centered coping strategies 0.764 .

\section{3) Self-esteem scale}

For the self-esteem scale used by Rosenberg [9]. The 
content of the scale is composed of a total of 10 questions, including 5 questions $(1,2,4,6,7)$ for positive self-esteem and the other 5 questions $(3,5,8,9,10)$ for negative self-esteem. In the case of negative questions, the higher the score processed by the reverse scoring is, the higher self-esteem self is, where the scale is made up of a 5 -point scale (1=not at all, 5=very much). In this study, the reliability of the scale was verified. As a result of that, Cronbach's $\alpha$ turned out 0.813 .

\section{4) Maladaptive perfectionism scale}

Through previous studies in term of multidimensional perfectionism, the sub-scales revealed as a feature of maladaptive perfectionism showing failure avoiding and evaluation anxious characteristics were selected and measured. Maladaptive perfectionism includes 3 factors: concerns about mistakes, doubts about performance, and socially imposed perfectionism. The same sub-factors were used in the study of Park and Cheng [10,11]. The scale used by Frost, Marten, Lahart and Rosenblate [12]. The scale is composed of 9 questions of concern sub-factors (1 9) and 4 questions of sub-factors for doubts about performance with a Likert-type 5-point scale (1=not at all, 5=very much).

Also using the multidimensional perfectionism scale of Hewitt and Flet [13]. The scale has a total of 9 items, made up of a 5-point scale (1=not at all, 5=very much). In this study, the reliability of the scale was verified with the result of 0.905 in Cronbach's $\alpha$.

\section{5) Suicidal ideation scale}

Reynnolds's Suicidal Ideation Questionnaire (SIQ) was used as an alternative [14]. It has a total of 17 questions, made up of a 5-point scale for suicidal ideation (1=not at all, $5=$ very much). The higher the score is, the higher the suicidal ideation is. In this study, the reliability of the scale was also verified, found to be 0.951 in Cronbach's $\alpha$.

\section{Data processing and analysis}

In this study, for data processing and analysis, SPSS version 18.0 (SPSS Inc., Chicago, USA) for Windows was used. First, to get basic statistics, the general socio-demographic characteristics of the sample were analyzed through frequency analysis. Factor analysis and reliability analysis of the measurement items were conducted. For factor analysis and reliability analysis, the characteristics of variables wee clarified to see whether each of items is tied for the factor under the same concept. These analyzes are also a way to verify the reliability and validity of measurement tools. In addition, t-test and ANOVA were used to measure the variation of variables according to socio-demographic characteristics. Next, correlation analysis and multiple regression analysis were used to verify the hypothesis of this study. Statistical significance was set 0.05 or less.

\section{RESULTS}

\section{Socio-demographic characteristics of subject}

In a sex ratio, $78 \%$ of the respondents were women and $22 \%$ of them were men, mostly female. In a grade, the first and second graders account for $84.8 \%$. In a type of residence, $73.1 \%$ were living in parents' house.

For father's final education, $62 \%$ responded high school graduates. For mother's final education, $70.6 \%$ answered high school graduates. The monthly average income was less than 1 2 million won in $22.3 \%$ and less than $2-3$ million won in $36.3 \%$. $81.4 \%$ of the respondents were found to have their opposite sex friend. Concerning monthly allowance, $24.9 \%$ of the respondents were found from $10 \sim 20$ thousand won and $31.4 \%$ of them from $20 \sim$ 30 thousand won. For religion, $51.4 \%$ of them answered no religion. The average credit turned out 3.5 or higher in $34.0 \%$ of the students, the highest ratio (excluding non-response). In terms of the characteristics of the target subjects, $41.4 \%$ were in the first grade. The questionnaire survey was given just after the first mid-term exams. Thus, they have never received credits, which thus contributed to a lot of non-responses. For college life satisfaction, $45.7 \%$ of the students answered so, $28.3 \%$ dissatisfied, and $26 \%$ satisfied. 


\section{Verification of the reliability of measurement tools}

Reliability refers to a degree to which no error is in the measurement results. In other words, it reflects the degree of systematic information about dispersion. As a method for evaluating the reliability of a measurement, many tools are used. In this study, the Chronbach's alpha coefficient was used for estimating the internal consistency. This method is intended to increase the confidence of a measurement tool by finding items that hinder reliability if multiple items are used and excluding the items from the measurement tool to measure the same concept. Generally, when the value of the Chronbach's alpha coefficient is 0.5 or more, it is considered relatively reliable. In this study also, the analysis was conducted in accordance.

In this study, reliability was measured for questions about college life stress, stress coping strategies, self-esteem, maladaptive perfectionism, and suicidal ideation as independent variables. The results of the analysis are shown in Table 1. Chronbach's alpha coefficient for college life stress was 0.791 in interpersonal relationship, 0.719 in interpersonal relationships. The Chronbach's alpha coefficient of the stress coping strategies turned out 0.873 in problem-oriented coping strategies, 0.764 in emotional centered coping strategies, 0.813 in self-esteem, 0.905 in maladaptive perfectionism, and 0.951 in suicidal ideation. The reliability of each item was over 0.5 , indicating very high reliability.

\section{Verification of the model}

1) Variation of suicidal ideation according to socio-demographic characteristics

T-test and ANOVA were conducted to examine the variation of socio-demographic characteristics on suicidal ideation factors. The results are shown in Table 2. The results of examining the variation of suicidal ideation according to socio-demographic characteristics suggested that only college life satisfaction showed significant results. In other words, the higher the dissatisfaction of college life is, the higher the suicidal ideation is.

\section{Correlation analysis of key variables}

The results of the correlation analysis between the variables included in the model of this study are shown in Table 3. From the correlation between suicidal ideation and variables, all variables were found $p<0.01$, related to all variables. Suicide ideation showed a significant positive correlation with maladaptive perfectionism, followed by college life stress, and emotion-centered stress coping strategies. In other words, suicidal ideation increased with higher maladaptive perfectionism, higher college life stress, including interpersonal relationships and facing college stress, and more emotional stress coping strategies used.

Also, suicidal ideation showed a significant inverse correlation in self-esteem, followed by university life satisfaction, and problem-oriented coping style. This suggests that suicidal ideation decreases with higher self-esteem, higher university life satisfaction, more problem-centered coping strategies used as aggressive stress coping approaches.

\section{Regression analysis}

To identify the influencing factors that affect suicidal ideation, multiple regression analysis was conducted The results are shown in Table 4.

Table 1. Reliability of campus life stress, stress coping type, self-esteem, suicide ideation, maladjustment perfectionism

\begin{tabular}{llccc}
\hline & Assortment & Average & Standard deviation & Chronbach's alpha \\
\hline \multirow{2}{*}{ Campus life stress } & Challenge & 3.06 & 0.67 & 0.791 \\
& Human relationship & 1.96 & 0.58 & 0.719 \\
Stress coping type & Problem centered & 3.19 & 0.85 & 0.873 \\
Self-esteem & Emotional centered & 3.09 & 0.98 & 0.764 \\
Suicide ideation & & 3.31 & 0.93 & 0.813 \\
Maladjustment perfectionism & 1.98 & 1.05 & 0.951 \\
\end{tabular}


Table 2. Variation of suicidal ideation by demographic characteristics

\begin{tabular}{|c|c|c|c|c|}
\hline \multirow{2}{*}{ Variables } & \multirow{2}{*}{ Assortment } & \multicolumn{3}{|c|}{ Suicide ideation } \\
\hline & & Average & Standard deviation & $p$-value \\
\hline \multirow[t]{2}{*}{ Gender } & Male & 1.99 & 0.87 & 0.896 \\
\hline & Female & 1.97 & 0.79 & \\
\hline \multirow[t]{4}{*}{ School year } & First grade & 1.98 & 0.81 & 0.766 \\
\hline & 2nd grade & 1.99 & 0.76 & \\
\hline & 3rd grade & 1.99 & 0.98 & \\
\hline & 4th grade & 1.78 & 0.84 & \\
\hline \multirow[t]{4}{*}{ Father education } & Middle School & 2.07 & 0.83 & 0.537 \\
\hline & High school & 1.94 & 0.75 & \\
\hline & College & 2.12 & 0.88 & \\
\hline & University & 1.97 & 0.93 & \\
\hline \multirow[t]{4}{*}{ Mother education } & Middle School & 2.08 & 0.80 & 0.661 \\
\hline & High school & 1.97 & 0.78 & \\
\hline & College & 1.86 & 0.91 & \\
\hline & University & 1.89 & 0.97 & \\
\hline \multirow[t]{6}{*}{ Monthly income } & Less than 1 million won & 2.21 & 0.80 & 0.051 \\
\hline & More than 1 million won and less than 2 million won & 2.15 & 0.81 & \\
\hline & More than 2 million won and less than 3 million won & 1.96 & 0.84 & \\
\hline & More than 3 million won and less than 4 million won & 1.90 & 0.74 & \\
\hline & More than 4 million won and less than 5 million won & 1.93 & 0.79 & \\
\hline & More than 5 million won & 1.62 & 0.67 & \\
\hline \multirow{2}{*}{$\begin{array}{l}\text { Friend of the } \\
\text { opposite sex }\end{array}$} & Have & 1.96 & 0.80 & 0.549 \\
\hline & No have & 2.03 & 0.82 & \\
\hline \multirow[t]{5}{*}{ Grades } & Above 4.0 & 1.96 & 0.87 & 0.286 \\
\hline & Above 3.5 & 1.86 & 0.78 & \\
\hline & Above 3.0 & 1.94 & 0.82 & \\
\hline & Above 2.5 & 2.28 & 0.68 & \\
\hline & Above 2.5 & 2.04 & 0.76 & \\
\hline \multirow[t]{5}{*}{ Pocket money } & Less than 100,000 won & 1.90 & 0.77 & 0.373 \\
\hline & More than 100,000 won and less than 200,000 won & 2.13 & 0.82 & \\
\hline & More than 200,000 won and less than 300,000 won & 1.93 & 0.82 & \\
\hline & More than 300,000 won and less than 400,000 won & 1.93 & 0.78 & \\
\hline & More than 400,000 won & 1.95 & 0.79 & \\
\hline \multirow[t]{2}{*}{ Religion } & None & 1.97 & 0.82 & 0.924 \\
\hline & Have & 1.98 & 0.79 & \\
\hline \multirow[t]{4}{*}{ Type of residence } & Parents' house & 1.92 & 0.77 & 0.182 \\
\hline & Rent/board & 2.19 & 0.88 & \\
\hline & Dormitory & 2.05 & 0.87 & \\
\hline & Etc & 2.26 & 0.91 & \\
\hline \multirow[t]{3}{*}{ College life satisfaction } & Unsatisfied & 2.26 & 0.85 & 0.000 \\
\hline & Neutral & 1.99 & 0.74 & \\
\hline & Satisfied & 1.63 & 0.74 & \\
\hline
\end{tabular}

Table 3. Correlation of variables

\begin{tabular}{|c|c|c|c|c|c|c|c|}
\hline Assortment & $\begin{array}{l}\text { Problem-oriented } \\
\text { coping style }\end{array}$ & $\begin{array}{l}\text { Emotion-centered } \\
\text { coping style }\end{array}$ & $\begin{array}{l}\text { Maladjustment } \\
\text { perfectionism }\end{array}$ & $\begin{array}{l}\text { Self- } \\
\text { esteem }\end{array}$ & $\begin{array}{l}\text { College life } \\
\text { satisfaction }\end{array}$ & $\begin{array}{l}\text { Challenge } \\
\text { stress }\end{array}$ & $\begin{array}{l}\text { Interpersonal } \\
\text { stress }\end{array}$ \\
\hline Emotion-centered coping style & $0.456^{\star *}$ & & & & & & \\
\hline Maladjustment perfectionism & $0.132^{\star \star}$ & $0.431^{\star \star *}$ & & & & & \\
\hline Self-esteem & $0.360^{\star \star}$ & $-0.089^{\star \star}$ & $-0.312^{\star \star}$ & & & & \\
\hline College life satisfaction & $0.161^{* \star}$ & $-0.123^{\star *}$ & $-0.256^{\star \star}$ & $0.358^{\star \star}$ & & & \\
\hline Challenge stress & $0.010^{\star \star}$ & $0.398^{\star \star}$ & $0.503^{\star \star}$ & $-0.452^{\star \star}$ & $-0.427^{\star \star}$ & & \\
\hline Interpersonal stress & $0.023^{\star \star}$ & $0.346^{\star \star}$ & $0.406^{\star \star}$ & $-0.352^{\star *}$ & $-0.322^{\star *}$ & $0.588^{\star \star}$ & \\
\hline Suicide ideation & $-0.105^{\star *}$ & $0.343^{\star \star}$ & $0.489^{\star \star}$ & $-0514^{\star \star}$ & $-0.287^{\star \star}$ & $0.463^{\star \star}$ & $0.463^{\star *}$ \\
\hline
\end{tabular}

${ }^{* *} p<0.01,{ }^{*} p<0.05$. 
Table 4. Regression analysis of factors affecting suicidal ideation

\begin{tabular}{|c|c|c|c|c|}
\hline \multirow{2}{*}{ Model } & \multicolumn{2}{|c|}{ Unstandardized coefficients } & \multirow{2}{*}{$\begin{array}{c}\text { Standardized coefficients } \\
\beta\end{array}$} & \multirow{2}{*}{$\begin{array}{l}\text { Significance } \\
\text { probability }\end{array}$} \\
\hline & $\mathrm{B}$ & Standard error & & \\
\hline (Constant) & 1.408 & 0.515 & & 0.007 \\
\hline Gender (Man=1) & 0.286 & 0.117 & 0.139 & 0.016 \\
\hline School year $(4$ th grade $=1)$ & -0.124 & 0.152 & -0.045 & 0.416 \\
\hline Monthly income (above 5 million won=1) & 0.018 & 0.155 & 0.006 & 0.910 \\
\hline Friend of the opposite sex (have $=1$ ) & 0.160 & 0.121 & 0.074 & 0.186 \\
\hline Grades (above $3.0=1$ ) & -0.184 & 0.111 & 0.091 & 0.099 \\
\hline Religion (have=1) & -0.014 & 0.089 & -0.009 & 0.871 \\
\hline Problem-oriented coping style & -0.131 & 0.122 & -0.081 & 0.284 \\
\hline Emotion-centered coping style & 0.321 & 0.134 & 0.173 & 0.018 \\
\hline Maladjustment perfectionism & 0.317 & 0.098 & 0.217 & 0.001 \\
\hline Self-esteem & -0.454 & 0.102 & -0.314 & 0.000 \\
\hline College life satisfaction & -0.067 & 0.068 & -0.059 & 0.325 \\
\hline Challenge stress & 0.030 & 0.093 & .025 & 0.752 \\
\hline Interpersonal stress & 0.294 & 0.096 & 0.217 & 0.003 \\
\hline \multicolumn{5}{|c|}{$R^{2}=0.461$, Adj. $R^{2}=0.425, F=12.643, p=0.000$} \\
\hline
\end{tabular}

Self-esteem, maladaptive perfectionism, interpersonal stress, gender, and emotion-centered stress coping strategies had a significant influence on suicidal ideation. Especially, self-esteem was the most influential variable. In detail, suicidal ideation decreased with higher maladaptive perfectionism and higher interpersonal stress. Men showed higher suicidal ideation than women. In addition, suicidal ideation was less with more emotional-centered coping strategies used, more passive stress coping strategies used, and lower self-esteem.

In addition, this regression model was statistically significant $(p<0.01)$, and the independent variables included in the regression model, namely, the explanatory variables, accounted for $46.1 \%$ of the suicidal thoughts variation as dependent variables.

\section{DISCUSSION}

This study attempted to propose implications for alleviating suicidal ideation in college students by diagnosing their suicidal problems and identifying an impact on their suicidal ideation. College life is a time of transition from adolescence to adulthood. It is a time to start an independent life and solve problems directly [15]. As mentioned earlier, the number of deaths due to suicide among 20 to 24 year-olds college students is much larger than the 15 to 19 year-olds confronted with confusing and frightening environments. It means that there are many cases where suicide is considered or impulsive suicide is attempted due to difficulty in confronting confused and fearful environment. Therefore, we analyze the factors affecting the suicidal ideation of college students through previous research, and analyzed empirically the relationship between these factors and college students, setting the college life stress, stress coping, self-esteem, and maladjustment completeness as independent variables. The results of analyzing the variation of suicidal ideation according to socio-demographic characteristics showed a significant difference in college life satisfaction. In other words, suicide ideation was severe in the group with low college life satisfaction. This suggests efforts to improve college serves to be effective for mitigating suicidal ideation. Also, the less patents' monthly income was, the higher suicidal ideation was. This means that the lower parents' income was, the higher the suicidal ideation was. If household income is low, the students fail to cover the expenses required to socialize with friends. This leads to experience relative deprivation and are faced with economic problems such as college tuition problems. In addition. because of the economic situation in their home, they feel pressure to get a job. This eventually affects suicidal ideation. It is thus necessary to provide them with a social 
support base. As a result of analyzing the correlation among stress coping strategies, self-esteem, maladaptive perfectionism, college life satisfaction, and suicidal ideation in college students, suicidal ideation was relevant in all variables. College life stress, emotion-centered stress coping strategies, and maladaptive perfectionism were found to have a positive correlation. This suggests that suicidal ideation increases with higher college life stress, more emotion-centered stress coping strategies used as passive approaches, and higher maladaptive perfectionism. This also indicates that suicidal ideation decreases with more problem-oriented coping strategies used as active coping approaches against stress, higher university life satisfaction, and higher self-esteem. Kim reported that emotional stress coping strategies had a significant effect on suicidal ideation [16].

From these results, stress has a close connection with suicidal ideation $[17,18]$. Thus, it is required to develop a solution that can be resolved immediately without accumulating stress. As a result, those who are vulnerable to stress need to be monitored through a continuous stress management program, which will thus contribute to prevent suicide. Emotion-centered strategies is an effort to control stress-related emotions. The result that emotion-centered strategies are related to suicidal ideation. Therefore, it is through that college students in transition to move to adulthood from adolescence are emotionally vulnerable enough to think about suicide to flee from the hard reality that they face.

As a result of the regression analysis of factors influencing suicidal ideation, a positive correlation was found between male students and maladaptive perfectionism, interpersonal stress, and emotion-centered coping strategies. In self-esteem, a negative correlation was found with male students. That means that male students show higher suicidal ideation as they are exposed to higher interpersonal stress, use more emotional coping strategies, and have a higher tendency of maladaptive perfectionism. It seems that suicidal ideation in college students is lower with higher self-esteem. Among significant variables, especially, self-esteem had the greatest effect.
This suggests that self-esteem is the direct cause of suicide ideation. The relationship between maladaptive perfectionism and suicidal ideation supports the previous studies conducted overseas [19]. Therefore, in order to prevent suicide in college students, communities need to provide education and training programs to develop interpersonal their skills, improve their stress coping strategies, and alleviate their tendency of maladaptive perfectionism. Especially among many variables, the effect of self-esteem was the highest. The results of this study are consistent with previous reports $[19,20]$. Thus, it is considered important to search for a multi-faced scheme by developing and operating a self-esteem improving program in a more aggressive way using various media. However, in this study, general college students were sampled. Thus, a high risk of suicide group with previous suicidal attempts, depression, mood disorders, and mental illness was not distinguished. Therefore, it is hard to generalize the sample. For this reason, national research should be conducted, based on an even ratio sampling. In addition, there are various factors that influence suicidal ideation in college students. However, all the factors were not considered. In subsequent studies, the inclusion of more diverse factors would lead to meaningful studies.

\section{요 약}

본 연구의 목적은 남녀 대학생을 대상으로 사회인구학적 특 성과 대학생활 스트레스, 스트레스 대처방식, 자아존중감, 부적 응적 완벽주의가 자살생각에 미치는 영향을 규명함으로써 대학 생의 자살예방정책 마련을 위한 시사점을 제공하는데 있다. 부 산경남지역 대학생 350 명을 대상으로 자기기입식 설문조사방 법으로 자료를 수집하여 실증 분석하였다. 본 연구의 주요 결과 를 요약하면 다음과 같다. 첫째, 자살생각은 사회인구학적 특성 중 대학생활 만족도에서 통계적으로 유의한 차이를 보였다. 즉, 대학생활만족도가 낮은 그룹에서 자살생각이 강했다. 둘째, 제 변수들의 상관관계를 분석한 결과, 자살생각은 자아존중감, 대 학생활 만족도, 적극적 스트레스 대처방법인 문제중심 스트레 스 대처방식 순으로 뚜렷한 역의 상관관계를 보이고 있고 반면 에, 부적응적 완벽주의, 대학생활 스트레스, 소극적 스트레스 대 처인 정서중심 스트레스 대처방식 순으로는 뚜렷한 정의 상관 
관계를 보였다. 즉 자아존중감이 높을수록, 대학생활 만족도가 높을수록, 문제중심 스트레스 대처방식을 사용할수록 자살생 각이 낮아지고, 부적응적 완벽주의가 높을수록, 대학생활 스트 레스가 높을수록, 정서중심 스트레스 대처방식을 사용할수록 자살생각이 높아지는 것으로 분석된다. 셋째, 연구 대상자의 자 살생각에 영향을 미치는 요인을 규명하기 위한 회귀 분석의 결 과, 부적응적 완벽주의, 대인관계 스트레스, 남학생, 정서중심 스트레스 대처방식 순으로 유의한 정의 영향을 미치는 것으로 나타났고, 자아존중감은 유의한 역의 영향을 미치는 것으로 나 타났다. 특히 자아존중감의 영향이 가장 컸다. 즉, 부적응적 완 벽주의가 높을수록, 대인관계 스트레스가 높을수록, 여학생보 다 남학생에서, 정서중심 스트레스 대처방식을 사용할수록 자 살생각이 높아지고, 자아존중감이 높을수록 자살생각은 낮아 지는 것으로 분석된다. 이상의 결과를 종합하면, 대학생활만족 도를 높이기 위한 노력이 대학생의 자살생각을 완화시키는 효 과가 있으며, 대학생의 자살예방을 위해서는 대인관계 기술 향 상과 스트레스 대처방식의 개선, 부적응적 완벽주의 성향의 완 화, 그리고 자아존중감 강화를 위한 교육 및 훈련이 필요함을 시 사한다. 특히 대학생의 자아존중감 향상을 위한 다각적인 방안 의 모색이 중요하다고 판단된다.

\section{Acknowledgements: None \\ Funding: None \\ Conflict of interest: None}

\section{REFERENCES}

1. Statistics Korea. Mortality by major causes of death per 100,000 population [Internet]. Daejeon: Statistics Korea; 2017 [cited 2017 November 27]. Available from: http: //kosis.kr/statHtml/statHtml.do?orgId=101\&tblId=DT_2KAAC13_O ECD\&conn_path=I2.

2. Statistics Korea. Cause of death in 2016 [Internet]. Daejeon: Statistics Korea; 2017 [cited 2017 November 27]. Available from: http://kostat.go.kr/portal/korea/kor_nw/2/6/1/index.board? bmode=read\&aSeq $=363268$.

3. World Health Organization. Preventing suicide: A global imperative [Internet]. Geneva: WHO; 2017 [cited 2017 November 27]. Available from: http://apps.who.int/iris/ bitstream/10665/ 131056/1/9789241564779_eng.pdf?ua=1\&ua=1.

4. Statistics Korea. Statistics of causes of death in 2010 [Internet]. Daejeon: Statistics Korea; 2017 [cited 2017 November 27].
Available from: http://kostat.go.kr/portal/ korea/kor_nw/2/6/ 1/index.board?bmode=read\&aSeq=250282.

5. Reynolds W. Psychometric characteristics of the adult suicidal ideation questionnaire in college students. J Pers Assess. 1991; 56(2):289-307.

6. Chun GG, Kim GH. Development of the life stress scale for college students: A control theory approach. Korean Journal of Clinical Psychology. 1991;10(1):137-158.

7. Lee CS, Kim YJ. Moderated effects of coping strategies of stress: Based on gender differences of university students. Studies on Korean Youth. 2004;15(2):183-213.

8. Folkman S, Lazarus RS. If it changes it must be a process: study of emotion and coping during three stages of a college examination. J Pers Soc Psychol. 1985;48(1):150-170.

9. Rosenberg M. Society and adolescent self-image. Princeton, NJ: Princeton University Press; 1965. p326

10. Park K. The moderating and mediating effects of problem solving and evaluative concerns perfectionism on the relationship between negative life stress and depression. Korean Journal of Health Psychology. 2004;9(2):265-283.

11. Cheng SK. Life stress, problem solving, perfectionism, and depressive symptoms in Chinese. Cognitive Therapy and Research. 2001;25(3):303-310.

12. Frost RO, Marten P, Lahart C, Rosenberg R. The dimensions of perfectionism. Cognitive Therapy and Research. 1990;14(5): 449-468.

13. Hewitt PL, Flett GL, Weber C. Dimensions of perfectionism and suicide ideation. Cognitive Therapy and Research. 1994;18(5): 439-460.

14. Reynolds WM. Psychometric Characteristics of the adult suicidal ideation questionnaire in college students. J Pers Assess. 1991;56(2):289-307.

15. Park JY, Park SM. Influence of college adjustment and social support on career development level of college students who majors in health or social welfare. Korean J Clin Lab Sci. 2017;49(3):180-186.

16. Kim JJ, Cho GP. The effect of stress and stress-coping on adolescents' suicidal ideation and plans. Korea Journal of Counseling. 2011;12(1):301-314.

17. Jung JR, Kim EY, Choi SA, Lee YJ, Kim JK. The relation between stress of college life and suicidal ideation: Mediating effects of perfectionistic concern over mistakes, social support, and depression. Korean Journal of Counseling and Psychotherapy. 2015;27(2):325-349.

18. Choi YJ. Stress, suicidal ideation, and protective factors in college students. Studies on Korean Youth. 2012;23(3):77-104.

19. Ahn SY, Choi BY, Kim JH. Meta-analysis on variables related to suicidal ideation among college students. The Korean Journal of School Psychology. 2015;12(3):385-405.

20. Jung HY, Lee KS. A study on the stress, self-esteem, mental-health and suicidal ideation in nursing students. Journal of Korean Clinical Health Science. 2015;3(2):328-339. 